AN official memorandum communicated to the German Reichstag lately gives some details about the Marshall Archipelago, of which Germany has just assumed the protectorate. It includes thirty lagoon islands or atolls, none of which rise more than ten feet above the sea. The vegetation is limited to the coca palm, the bandanas, and the bread-fruit tree. The native fauna are a small lizard, land- and water-crabs, and a few wild pigeons. There are absolutely no springs or running water, the inhabitants being dependent on rain-water caught in hollows and clefts in the rock, which rapidly becomes brackish on account of the porous medium. The group naturally divides itself into two chains, the eastern or Ratack, and the western or Ralick. It is in this latter that the largest island of the whole group, Jaluit, is situated. It has an area of about thirty-five square miles, contains about 1000 inhabitants, and possesses a good harbour. On it are the factories of the European and American Companies trading to the group. American missionaries have also stations there, the work of which is carried on by Sandwich Islanders.

A RUssian scientific expedition to proceed to China is being organised under the direction of Dr. Piassetsky. The expenses will be provided partly by the Imperial Exchequer, and partly by the Moscow Commercial Committee.

THE French Minister of Public Instruction has informed the Geographical Society of Paris that he has added to the Committee on historical and scientific work a section on historical and descriptive geography.

In the last number of the Mittheilungen of the Vienna Gesgraphical Society (Bd. xxviii. No. I2) Herr Becker describes the "Blue Grotto of Busi," one of the Dalmatian Islands, which has only recently been discovered, and which owes its name to a peculiar light effect. It greatly resembles the celebrated "Grotta azzura" at Capri, but seems to be inferior to the latter in several respects. Herr Wienkowski has a curious paper on the "Pomeranian Kassubs," a remnant of the Wendic peoples which once inhabited the districts between the Saale and Elbe on one side and the Vistula on the other. The sub-title of the paper is, "A Contribution to the Ethnography of Germany." The Kassubs, although, according to a popular song of their own, as numerous as the sand on the sea-shore, now are very few in number, and their special characteristics are disappearing with the spread of a common school education. The writer gives an historical sketch of the Kassubs, describes their occupations, dwellings, clothing, food, marriage and harvest customs, the speech, and concludes with a few words on their proverbs and tales. Prof. Palacky gives a brief account of attempts at acclimatisation of plants in the Congo region, and a letter from Dr. Lenz from the Congo is also published.

\section{THE BENEFITS WHICH SOCIETY DERIVES FROM UNIVERSITIES}

I $O$ be concerned in the establishment and development of a university is one of the noblest and most important tasks ever imposed on a community or on a set of men. It is an undertaking which calls for the exercise of the utmost care, for combination, co-operation, liberality, inquiry, patience, reticence, exertion, and never-ceasing watchfulness. It involves perplexities, delays, risks. Mistakes cannot possibly be avoided; heavy responsibility is never absent. But history and experience light up the pioblem; hope and faith give animation to the builders when they are weary and depressed. Deeply moved by these considerations, I desire to bring before you, my colleagues in this work, without whose labours all would be a failure, you who are Trustees, and you who are teachers, before the c.tizens of Baltimore, and before this company of students pressing forward to take the places of authority in the work of education and administration-before you all, my friends, I wish to bring some aspects of university life, which, if not new, may perhaps be stated in terms which are fresh, with illustrations drawn from our own experience.

I ask you to reflect at this time on the Relation of Universities to the Progress of Civilisation, and I begin by assuming that we are agreed substantially on the meaning of both these terms. The word university, as applied to a learned corporation, is several hundred years old, and in all times and lands has embodied the idea of the highest known agency for the promo-

I An Address by D. C. Gilman, President of the Johns Hopkins University. tion of knowledge and the education of youth. Civilisation is a new word, hardly introduced a century ago, though the idea which it embodies is as old as organic society. Guizot, to whose eloquence we owe the popularity of this term, avoids its formal definition, declering in general terms that civilisation is the grand emporium of a people, in which all its wealth, all the elements of its life, all the powers of its existence, are stored up. "Wherever," as he goes on to say, "the exterior condition of man becomes enlarged, quickened, or improved, wherever the intellectual nature of man distinguishes itself by its energy, brilliancy, and its grandeur; wherever these two signs concur, and they often do so, notwithstanding the gravest imperfections in the social system, there man proclaims and applauds civilisation." Assuming, then, that by university the highest school is understood, and by civilisation the highest welfare of mankind, let us inquire into the influence which the advancement of knowledge by means of superior educational establishments has exerted or may exert upon the progress of society.

A little reflection will remind us of five great agencies by which modern Christian civilisation is helped forward: first, THE FAMILY, unit of our social organisation, recognised by Aristotle as the basis of society, and styled by modern philosophers "the focus of patriotism" (Lieber), and the very "starting-point of social morality" (Maurice); next, TRADE or COMMERCE, the exchange of one man's products for another's, the traffic between communities and nations; third, LAW and CUsTom, written and unwritten, the enforcement of duties and defence of rights, the equitable adjustment of conflicting claims ; fourth, REI.IGION, the acknowledgment of personal responsibility to an infinite and all-controlling Power. The last to be named is KNOWLEDGE, the recorded of servations and experience of our race in ancient and in modern times, or, in other words, SCIENTIA, science in its broadest significance.

These five influences working in dwelling houses, market places, state houses, churches, libraries, and schools, control our modern life; and that state of society is the best, in which domestic virtue, mercantile honour, and the freedom of exchange, obedience to law, pure and undefiled religion, and the general diffusion of knowledge, are the dominant characteristics. We are only concerned at present with the last of these five factors.

The means by which our race has acquired knowledge and preserved its experience are manifold. The inhabited world is a great laboratory, in which human society is busy experimenting. Observation, exploration, and reflection have been allied in interpreting the physical characteristics of the globe, ever since the primæval law, "Subdue the earth," was heard by primitive man ; experiments in social organisation have also been made on a colossal scale, and in little microcosms; war has tanght its pitiful lessons; superstition, irreligion, vice, and crime, as well as literature, art, law, religion, and philosophy, have all been teachers ; customs, traditions, epics, creeds, codes, treaties, inscriptions, parchments, books, pyramids, temples, statues, museums, schools, pulpits, platforms, have all been employed to perpetuate and diffuse the knowledge which has been acquired; but ever since Europe emerged from the darkness of the Middle Ages, Universities have been among the most potent of all agencies for the advancement and promulgation of Learning. Their domain, the republic of letters, has been wider than the boundaries of any state ; their citizens have not been restricted to any one vocabulary; their acquisitions have been hid in no crypt. They have gathered from all fields and distributed to all men. Themes the most recondite, facts the most hidden, relations the most complex, have been sought out and studied, that if possible the laws which govern the world might be discovered, and man made better.

In one of our halls there hangs a diagram which I never pass without pausing to think of its significance, listening as I would before the sphinx to discover if it has any message for me. It contains a list of European universities founded since the dawn of modern states-a period of more than seven centuries, a list of over two hundred names. Every state in Europe, every great city, has its high school. Popes, emperors, kings, and princes have been their founders; ecclesiastics, reformers, repubirs, municipalities, private citizens, munificent women, have contributed to their maintenance. Wherever European civilisation has gone, the idea of the university has been carried with it. to North and South America, to Australia, even to India, China, and Japan; it came with the Virginians to Williamsburg, with the New Englanders to Cambridge and New Haven; it was planted in California before there was an organised state on the Pacific slope. 
The idea is often vague, sometimes perverted, commonly halfdeveloped, at times inflated, - nevertheless it contains this principle of life, that in every civilised community there must be a high school, capping, crowning, binding, all other institutions for the advancement of learning.

Allow me to turn your attention to some historical illustrations. Notwithstanding the great renown of Charlemagne, greatest of monarchs between Cæesar and Napoleon, the fact that his empire was founded upon the principle of superior education is not so familiar; but a recent writer (Mr. Mullinger) has given us an instructive essay on the schools of Charles the Great, and a still more recent writer (Mr. R. L. Poole) has made a study of their influence. "If his reign marks the dividing line between ancient and modern history," says the latter, "it is not only by virtue of its political facts but also because he begins the education of the Northern races-fitting them in time to rule the world as the Romans had done before them."

A monk of St. Gall has preserved for us what purports to be an authentic account of the mode in which learning was introduced into the Frankish empire, and although the extract is long I am sure it will not weary you, as I read from the translation of Mr. Poole.

"When," says the monk, "the illustrious Charles had begun to reign alone in the western parts of the world, and the study of letters was everywhere well-nigh forgotten, in such sort that the worship of the true God declined, it chanced that two Scots from Ireland lighted with the British merchants on the coast of Gaul, men learned without compare, as well in secular as in sacred writings; who, since they showed nothing for sale, kept crying to the crowd that gathered to buy, "If any man is desirous of wisdom, let him come to us and receive it ; for we have it to sell.' This therefore they declared they had for sale, since they saw the people to traffic not in gifts but in salable things, so that they thus might either urge them to purchase wisdom like other goods, or, as the events following show, turn them by such declaration to wonder and astonishment. At length their cry being long continued was brought by certain that wondered at them or deemed them mad, to the ears of Charles, the king, always a lover and most desirous of wisdom: who, when he had called them with all haste into his presence, inquired if, as he understood by report, they had wisdom verily with them. 'Yea,' said they, "we have it and are ready to impart to any that rightly seck it in the name of the Lord.' When therefore he had inquired what they would have in return for it, they answered, 'Only proper places and noble souls, and such things as we cannot travel without, food and wherewith to clothe ourselves.' Hearing this he was filled with great joy."

Several instances in modern history may be cited, in each of which the close of a great civil commotion has been marked by the foundation of a university. One of them is quite familiar. A little more than three hundred years ago, Leyden, so lately freed from the horrors of a siege, "so lately the victim of famine and pestilence, had crowned itself with flowers." The university was to be inatigurated. In the grand procession rode a female figure, the Holy Gospel, attended by Four Evangelists; then came other allegorical figures, emblematic of Law, Medicine, and the Liberal $\Lambda$ rts, and then the magistrates and dignitaries. Down the Rhine floated the semblance of Apollo and the Muses, and each Professor, as he advancerl, "was kissed by Apollo and all the nine Muses in turn," whose salutation found further expression in "an elegant Latin poem." I have taken these statements, as you doubtless surmise, from the pages of Motley, to show you the enthusiasm of the Low Countries in respect to their university; but a truer impression of the work then inaugurated would be given by recounting the roll of the great men who have taught in that university and of the great scholars whom they have trained. Grotius, Descartes, Scaliger, Boerhaave, Wyttenbach, Arminius, and Gomar, were among the early scholars who resided in Leyden, and the list might be extended until it reached our own contemporaries and our own countrymen.

A few years earlicr, when the Reformation in England was nearly completed, Henry the lighth reorganised the University of Cambridge, and laid the foundations of that splendid college, which might be called a university in itself, if ever a college could clain the more comprehensive name, Trinity College, which before the century had passed, trained for the world that great triumvirate whose statues glorify the approach to the chapel, Isaac Barrow, Lord Bacon, and Sir Isaac Newton, qui genus humanum ingenio superavit.

The foundation of the University of Berlin is a noteworthy modern instance of the erection of a great high school, in a time of national sorrow. The story has often been given, and was recently made the opening passage in an inaugural address by Helmholtz. Prussia had been overrun by France, the resources of the state were almost exhausted, but Frederick William the Third, led on by William von Humboldt, Stein, and other great intellects, determined to infuse new spirit into a despondent people, by conferring on them the greatest benefit which it was in his power to bestow, a university, founded on such a liberal plan, that it rose at once to the very front rank.

So within our recollection, that monarch's greater son, the Emperor William, when Strasburg had been reclaimed by Germany, determined that it should be the seat of a university, and already that new foundation stands among the strongest and best of German high schools.

These examples of universities founded each of them at the close of a sharp social crisis, often occurs to my uind when I remember that our foundation was projected at the close of a civil war, and was established in the firm belief that it would bind together in the love of Literature and Science all classes and all creeds. A physician who has lately died in communion with the Roman Catholic Church, has often said to me, "I tell everybody that there is one thing on which we can all agree, and that is the university," and another, of the same religious creed, has just written me, "I sincerely hope to see your prediction as to all Christian forces come true. Life is too short, and there is too much good to be done, to have any force or energy wasted in bar'en controversy."

I have made these historical allusions, most of which I am well aware are familiar, in order to raise the questions: Why is it that universities are so highly esteemed? What are the advantages which follow their foundation? Remembering that $a$ university is the best organisation for the liberal education of individuals, and the best organisation fir the advancement of science, apply the double test,-what is done for personal instruction, and what is done for the promotion of knowledge, and you will be able to judge any institution which assumes this name.

Ask, first, is it a place of sound education? Are the youth who are trained within its walls honest lovers of the truth, -are they learned, are they ready, are they trustworthy? When they leave the academic classes, do they soon find a demand for their services? Do they rise in professional life? Are they sought for as teachers? Do they show aptitude for mercantile, administrative, or editorial life? Do they acquit themselves with credit in the public service? Do the books they write find publishers? Do they win repute among those who have added to the sum of human knowledge? Have they the power of enjoying literature, music, art? Can they apply the lessons of history to the problems of our day? Are they always eager to enlarge their knowledge? Do they become conservative members of society, seeking for progress by steady improvements rather than by the powers of destruction and death? Are they useful, courteous, co-operative citizens, in all the relations of life? Do the charities, the churches, the schools, the public affairs of the community, receive their constant consideration? Are there frequent manifestations among them of unusual ability in science, in literature, in oratory, in administration? As the roll of the alumni increases and the graduates are counted by hundreds and not by scores, does it appear that a large proportion are men of honourable, faithful, learned, and public-spirited character? These are the questions by which, as the years go on, a university is to be tested, or to sum all questions in one, is it proved to be a place for the development of manliness?

I beg leave to dwell a little longer upon thi: text, because I think there is danger of its importance being overlooked. The material resources of a university, the aggregate numbers who attend its courses, its numerous buildings, its great collections, appeal to everybody, - only those who look at results are competent to give a conclusive opinion, and their opinion cannot be formed in one decade. A generation is the briefest period for a fair review. When the year of our Lord 1900 comes, this foundation will be a quarter of a century old. To that remote tribunal we appeal for judgment on our work of to-day. But we may anticipate this final verdict, and ascertain by our own inspection and inquiry what is done in any institution for the education of youth, what opportunities are afforded, how those advantages are regarded by the most intelligent young men, and what kind of scholarship is developed at the termination of the academic course. 
Here let me protest against the common method of estimating intellectual work by numerical standards alone. I have heard it said that some men are possessed by a statistical devil. They can only think in figures: they will ask, in respect to a new acquaintance, how much is he worth ; of a library, how many volumes; of an orchestra, how many pieces; of a college, how many students. I have known the expenses of an institution made a dividend, and the number of scholars the divisor, the quotient representing the cost of each pupil. All this is wrong, absolutely and wholly wrong. If such a standard were allowable, the largest number of scholars taught by the cheapest teacher would be the greatest success. It is not the number but the quality of students which determines the character of a high school. It is important to count; it is better to weigh.

Having spoken of what the university does for individuals, I add that it has a second function. It benefits associated as well as inciividual man. It renders services to the community which no demon of statistics can ever estimate, no mathematical process ever develop. These functions may be stated as the acquisition, conservation, refinement, and distribution of knowledge.

These carefully chosen words I proceed to explain.

I. It is the business of a university to advance knowledge every professor must be a student. No history is so remote that it may be neglected; no law of mathematics is so hidden that it may not be sought out; no problem in respect to physics is so difficult that it must be shunned. No love of ease, no dread of labour, $\mathrm{n} n$ fear of consequences, no desire for wealth, will divert a band of well chosen professors from uniting their forces in the prosecution of study. Rather let me say that there are heroes and martyrs, prophets and apostles of learning as there are of religion. To the claims of duty, to the responsibilities of station, to the voices of enlightened conscience, such men respond, and they throw their hearts into their work with as much devotion, and as little sclfishness, as it is possible for human nature to exhibit. By their labours knowledge has been accumulated, intellectual capital has been acquired. In these processes of investigation the leading universities of the world have always been engaged.

This is what laboratories, museums, and libraries signify. Nothing is foreign to their purpose, and those who work in them are animated by the firm belief that the advancement of knowledge in any direction contributes to the welfare of man. Nor is rescarch restricted to material things; the scholars of a university are equally interested in all that pertains to the nature of man, the growth of society, the study of language, and the establishment of the principles of intellectual and inoral conduct.

2. Universities are conservative. They encourage the study of the history, the philosophy, the poetry, the drama, the politics, the religion, in fine, the experience of antecedent ages. Successors of the ancient monasteries, they keep alive in our day the knowledge of ancient languages and art, enrich the literature of our mother tongue, hold up to us the highest standards of excellence in writing, and enable us to share in the thoughts of the noblest of our race. Let me especially remind you that to the universities men turn instinctively for light on the interpretation of the Scriptures. When new manuscripts are discovered, or new versions are proposed, or new monuments are unearthed, it is $t$, the universities, where the knowledge of ancient ind remote tongues has been cherished, that the religious world looks for enlightenment and guidance. Their dominant influence is highly spiritualising; I would even go farther and say that it is truily religious. I am not unmindful that within the academic circles men are found whose spiritual insight is but dim-so it is in all other circles-but I assert, without fear of contradiction, that the influence of study is, on the whole, favourable to the growth of spiritual life, to the development of uprightness, unselfishness, and faith, or, in other words, it is opposed to epicureanism and materialism. In belief, there are tides as there are in the ocean, ebb and flow, ebb and flow; but the great ocean is there, with its deep mysteries, unchanging amid all superficial changes. Faith, with all its fluctuations, is as permanently operative in human thought as Knowledge.

3. Universities are refining. They are constantly, by laborious processes, by intricate systems of co-operation, and by ingenious methods, engaged in eliminating human errors and in submitting all inherited possessions to those processes which remove the dross and perpetuate the gold. No truth which has once been discovered is allowed to perish,-but the incrustations which cover it are removed. It is the universities which edit, interpret, translate, and reiterate the acquisitions of former generations both of literature and science. Their revelation of error is sometimes welcomed, but it is generally opposed; nevertheless the process goes on, indifferent alike to plaudits or reproaches. If their lessons are hard to the beginners, they lead the persevering to high enjoyment.

4. Universities distribute knowledge. The scholar does but half his duty who simply acquires knowledge. He must share his possessions with others. This is done in the first place by the instruction of pupils. Experience has certainly demonstrated that, with rare exceptions, those men are most learned who produce most. The process of acquiring seems to be promoted by that of imparting. The investigator who is surrounded by a bright circle of friendly inquisitors and critics finds his best powers developed by this influence. Next to its visible circle of pupils, the university should impart its acquisitions to the world of scholars. Learned publications are therefore to be encouraged. But beyond these formal and well recognised means of communicating knowledge, universities have innumerable less obvious, but not less useful, opportunities of conveying their benefits to the outside world.

These general principles $I$ propose to illustrate by asking you to go with me around the circle of the sciences, that we may observe the part which universities have taken, or should take, in respect to the various departments of knowledge.

Let me begin by saying that a university should discover and teach all that can be known of the Human Body. If you ask me why this is so important, I reply, in order that every one may be able to lead a healthier, stronger, and more rational life than is now possible for the want of more knowledge. Hospitals are essential to alleviate sufferings which have been encountered physical training is of great value; but still more important to humanity is the laboratory in which are studied the laws of life. A celebrated physiologist declares that "a hundred years of life is what Providence intended for man," and others tell us that most of our minor ailments may easily be avoided, ánd the number of efficient days may be largely increased. Science has proved that many diseases which used to scourge the civilised world may be prevented, and it has recently brought us within sight of new discoveries which will still further interrupt the progress of pestilence. The discoveries of anæsthetics have narvellously alleviated the sufferings of humanity. The causes and remedies of cerebral excitement and degeneration have never been understood as now, and the possibilities have never been so great for the restoration to their normal activity of the powers which have been alienated. In view of these great results and of these anticipations, it is clearly the duty of a university to study all the forms and functions of life which are manifested in organisms lower than man, all the laws which govern animal and vegetable growth, all that can possibly throw light on human physiology.

Those who are devoted to research of this kind, revealing with their microscopes the structure and the life-histories of the minutest organisms, are constantly, and in most unexpected ways, coming upon new illustrations of the plan of creation, which have an important bearing upon the welfare of man. 'They are the interpreters of nature and the benefactors of humanity ; and I do not hesitate to add that if there is any branch of learning which at the present time deserves the most gencrous support, it is surely l3iology, because of its obvious relations to the health and happiness of every human being. I cannot but think that those who oppose its study will be ranked in future years among the obscurantists of the nineteenth century.

( $T$ o be continued.)

\section{PRJEVALSKY'S EXPLORATIONS IN CENTRAL ASIA}

THE last number of the Izvestia of the Russian Geographical Society (xxi. 3) contains a letter from M. Prjevalsky, dated Lob-nor, January 29, r885. After having spent a month at Tsaidam, the expedition undertook, in August, its journey towards the west. A special disease, called khasa by the Mongols, and consisting in a strong fluxion of all four feet, attacked fifty three camels of the caravan, as well as all the cattle of the Mongols, and compelled the expedition to stop for a fortnight. Only seven camels succumbed to the disease, and on September 18 the expedition resumed its further advance, following the foot-hills of the Kuen-Jun-that is, of the border- 